\title{
Continuity of Narratives: Reinterpretations of Polish Business History
}

Anna Pikos ${ }^{1}$

Submitted: 4.09.18. Final acceptance: 8.02.19

\section{Abstract}

Purpose: This article seeks to identify the similarities and differences in the narratives of corporate histories published in different periods of time.

Methodology: This study is based on a comparative content analysis of corporate histories of three pharmaceutical plants operating under the "Polfa" Union of the Pharmaceutical Industry based in Poland.

Findings: Corporate histories change depending on the period in which a given history is published. The study reveals that corporate history depends on the nature of the state authority in power at a given time.

Research limitations and implications: This exploratory study concentrates on examination of four corporate histories and contributes to the research on the "uses of the past" in organization studies. Nevertheless, it has several limitations, including a limited number of companies included in the analysis and the adoption of a qualitative approach only.

Originality and value: This is the first article that focuses on a comparative content analysis of corporate histories published at different times in search of the similarities and differences in the domain of corporate narrative.

Keywords: business history, narratives, corporate history, rhetorical histories, organizational longevity

JEL: N8

\footnotetext{
1 Kozminski University

Correspondence address: Kozminski University, 59 Jagiellonska St., 03-301 Warsaw, Poland, e-mail: apikos@kozminski.edu.pl; https://orcid. org/0000-0003-2002-1055
} 


\section{Introduction}

Recently, we can see a turn to organization theory in business history, and - more specifically - a turn towards culture and narrative (Foster et al., 2016; Smith and Simeone, 2017; Rowlinson and Delahaye, 2009). Historical narratives can be treated as organisational resources and used by managers strategically (Foster et al., 2016). This "narrative turn" brings attention to the narrativization of organisational life over time by means of stories (Maclean et al., 2016; Popp and Fellman, 2017).

The article is based on a qualitative content analysis of corporate histories published by some of the oldest Polish companies. In the article, the author utilizes a recently developed database of Polish companies (see Pikos and Olejniczak, 2017) that have been operating for more than 100 years to identify companies which have published corporate histories on multiple occasions under different political and socioeconomic conditions (e.g. in the 1960s, 1990s, 2000s).

This paper aims to provide preliminary answers to the following research question: "How does corporate narrative change under different socioeconomic conditions?". The paper will not be purely descriptive. The majority thereof will be devoted to a comparative content analysis of corporate histories published in different times in search of similarities and differences in the presented accounts. This approach will be inspired by a grounded theory and feature more analytical elements, including various qualitative coding techniques (Saldana, 2013).

This study makes two important contributions. First of all, this article contributes to the literature on historical narratives by investigating how corporate histories change in different periods of time. The paper concentrates on a comparative content analysis of corporate histories in search of common themes, dominant narrative, dominant logic, and reinterpretations of the business reality between and during wars, in the period of socialism and during the subsequent transition to market economy. Previous research concentrated on whether, why, when, and how firms adopt the strategic use of rhetorical history. But "we know less about how the practice originated” (Smith and Simone, 2017, p. 335)

Secondly, the context of this study may be interesting when studying Polish business history in Central and Eastern Europe (CEE). As stated by Amatori and Jones (2003), CEE is one of the regions that are underrepresented in the literature devoted to the subject. Therefore, this study may bring a new understanding of the development of historical narratives in CEE - in the region where historical perspective 
is essential (e.g. CEE countries were under USSR control for more than thirty years; see Morawski, 2018).

The article begins with a brief overview of linguistic turn and genre concept. I then proceed to describe the corporate histories and their role in historical studies. Next, I discuss the research methods and research approach used in this particular project, which is followed by a presentation of the results of this study. I finish with a discussion and interpretation of the findings.

\section{Linguistic and narrative turns}

Recently, one of the most prominent areas of interests in the discipline of humanities and social sciences has been the interest in narrativization leading to a focus on language (i.e. a text, a narrative, a story, and discussion) studied as the core element of a given organization. It has come to challenge the standard grounded notion of organizational theory based on ideas such as hierarchy, bureaucracy, and authority (Alvesson and Kärreman, 2000; Gotti, 2011). In the last decade, we could see how this linguistic turn influenced organizational analysis (Delahaye et al., 2009; Fairhurst, 2001). Researchers from the area of organization studies now reconsider their questions from textual and linguistic points of view, and argue that "the proper understanding of societies, social institutions, identities, and even cultures may be viewed as discursively constructed ensembles of texts" (Alvesson and Kärreman, 2000: 137). Nowadays language is more than just an element of a narrative structure or words that reflect themes, rules, and norms of behaviour (Putnam and Fairhurst, 2001). According to Alvesson and Kärreman (2000, p. 142), language is now perceived as:

- an active, autonomous, and productive mode of expression;

- the central object of study in social science;

- a rhetorical device for the creation of a credible research text;

- the very matter researchers work and struggle with;

- a carrier of power through its ability to order and constitute the social world; and a vehicle for the potential critical clarification of social issues.

There are two approaches to historical narrative. In the realist approach, managers can develop narratives that mirror the past. In the constructivist approach, managers interpret the past from the perspective of the present ("is a matter of invention"). But it is not only the choice of approach that influences the way the narrative is con- 
structed. It is also the actor's perception of the past that has an impact on the narrative (Foster et al., 2016, p. 5).

Business historians have started analysing how the social world has been created through narratives. This big interest in the narrative is rooted in the 'linguistic turn' of the 1970s. Scholars have started to focus more on the performative role of narratives and the way historical narratives are created and used to gain advantage. In the academic history the "linguistic turn emerged in its specific form as narrative turn due to the close link between the narrative as a genre and history as a discipline" (Mordhorst and Schwarzkopf, 2017, p. 1160-1161).

\section{The concept of genre}

Genre is a broad concept whose meaning is different both within and between various disciplines. It is "a process of linguistic and cultural formation and knowledge acquisition” (Delahaye et al., 2009, p. 28). Genre establishes a structure within which textual and social norms become meaningful, thus helping us understand the world and our culture (Delahaye et al., 2009).

According to Yates and Orlikowski (1992), genre is 'a literary and rhetorical concept that describes widely recognized types of discourse (e.g. a novel, a sermon)'. It can be used in different kinds of communication characterized by structural, linguistic, and substantive conventions (Yates and Orlikowski, 1992). Genre, rhetoric, and style have achieved a prominent rank in organization studies (Alvesson and Kärreman, 2000).

In this paper, the author follows a definition stating that "genre (...) is a type of discourse that tells the past of an organization, whether in print, on the web, or in the physical space of the organization's buildings" (Delahaye et al., 2009).

\section{Corporate histories}

History can be a strategic asset for companies (Foster et al., 2016). A corporate history is one of the symbolic resources which is "designed to create a shared origin and a common purpose, promoting a sense of continuity and commitment among organizational stakeholders" (Ybema, 2014: 495). Corporate histories are used for marketing an organization, inspiring action, and managing change. History gives 
structure and meaning in time (Suddaby et al., 2010). But history is a manageable corporate asset and it is an important part of corporate reputation. This assumption is based on the problem with the meaning of the word 'history'. Foster et al. (2016) treat past as a collection of bygone events and history as a mediated representation of what once occurred. There is some degree of interpretation of these bygone events. As stated by Carroll (2016, p. 194), philosophers claim that history refers both to the past itself and to the narratives or accounts that are constructed to represent the past in the present. That is why we can find "conflicting" views on history in the literature covering the subject in question. Histories, previously treated as repositories of knowledge (Teece and Pisano, 1994), have for some time now been treated by some researchers as a rhetorical instrument and an interpretive device used for manipulation purposes by both challengers and custodians of various institutions (McGaughey, 2013). Facts can be reinterpreted and embellished, becoming "dangerous devices in the hands of image makers" (Gabriel, 2004, p. 62). Individuals can change the meaning of the past, the present, and the future by telling different, even diverging accounts of the same events (Ybema, 2014). History can present the development of a company in "an apparently seamless, linear and concrete fashion” (Durepos et al., 2008, p. 63). Such company's ability to reconstruct and reinterpret what happened and what past events mean to it is the key area of interest of the concept of rhetorical history (Foster et al., 2016).

\section{Rhetorical history}

According to Suddaby et al. (2010), rhetorical history has been inspired by works of Boje (1991, 1995), Barry and Elmes (1997) and Czarniawska-Joerges (1997), who have determined the meaning of narratives and storytelling in organizations (Mordhorst and Schwarzkopf, 2017). At the beginning, the term of "organizational saga" was used in reference books to explain the way companies took advantage of stories, symbols, and traditions influencing their future performance. Sagas were used by companies to strengthen the understanding of their history and mission (Suddaby et al., 2010). Suddaby et al. (2010, p. 160) claim that rhetorical history, however, views the history of a company as "an organizational resource designed to confer identity, motivate commitment, and frame action amongst organizational stakeholders", and that it is a product of a given organization. Managers can utilize elements of collective memory to shape, re-shape, and communicate history and draw a narrative that creates cohesion and identification between a company and its external stakeholders. A relationship and connection with bigger social institutions underline legitimacy and generate competitive advantage (McGaughey, 2013). 
This tension between the two views on what history is has also led to different opinions on corporate history itself. On the one hand, we have business historians like Geoffrey Jones, who accept producing commissioned corporate histories based on archive business sources. On the other hand, we have scholars like Suddaby, who treat corporate history as one of the forms of rhetorical history being "produced for a strategic purpose by and for organization" (Carroll, 2016, p. 194). There is a debate on whether scholars should dismiss corporate histories as material without any academic depth (Jones and Sluyterman, 2003) or whether such histories should become a subject of an in-depth analysis as an "interesting, and hitherto neglected, cultural and organizational phenomenon" (Delahaye et al., 2009).

In this paper, I will analyse corporate histories using the concept of genre. So far, the discussion on corporate history has been considered in the context of a genre quite rarely (see Delahaye et al., 2009).

According to Carroll (2016, p. 193), "corporate history can be defined as a genre of written narrative story that has its object the story of a corporate body" - an entity with a name and legal existence. It always has a history - understood as having a past, as organization members having memories or having a narrative of the past. The latter, treated as a cultural phenomenon, can be a subject of a genre analysis (Delahaye et al., 2009).

\section{Methods}

As stated before, the research question that the paper will seek to answer is: "How does corporate narrative change under different socioeconomic conditions?". A bibliographic inquiry was made in the National Library of Poland in search of business stories written by the companies featured in the developed database. As it turned out, only $40 \%$ of the listed centenarian companies published corporate histories that summarized their achievements. Moreover, most of those histories were published only once during 1970s and 1980s.

After this preliminary analysis, the author of the paper started analysing the available corporate histories. The following criteria were applied in the analysis:

1) The corporate histories of the company must be published in different historical periods,

2) The corporate history must be presented as a narrative, 
3) The company must still exist.

4) The company must cover at least 20 years of existence in every corporate history.

After applying all these criteria, Zjednoczenie Przemysłu Farmaceutycznego "Polfa" ("Polfa" Union of the Pharmaceutical Industry) was selected as the company to be covered in more detail. In 1947-1982, Zjednoczony Przemysł Farmaceutyczny gathered all pharmaceutical plants that had a monopoly on their products and produced medicines and medical devices.

After World War II, most chemical-pharmaceutical companies disappeared. In 1945, the premises and facilities of those companies were taken care of spontaneously by their former employees, working at those facilities before the liberation. They started removing the effects of damage and restoring the destroyed infrastructure to a condition that would make it possible to recommence the process of production. Right after the war, the facilities were taken over by a state management body, and in 1950, they were nationalized. The newly-formed people's authority, aware of the significance of the pharmaceutical industry, decided to establish a pharmaceutical industry organization. The first such organization created in the Polish People's Republic was Zjednoczenie Przemysłu Organicznego i Farmaceutycznego (Union of the Organic and Pharmaceutical Industry), which was later renamed to Zjednoczone Zakłady Przemysłu Farmaceutycznego (United Pharmaceutical Industry Works). In 1951, the minister of the pharmaceutical industry established state companies and changed the names of the operating pharmaceutical plants in a way that the location of a given plant was the basis for its name, e.g. Tarchomińskie Zakłady Farmaceutyczne (Tarchomin Pharmaceutical Works). In 1961, the state chemical-pharmaceutical plants were united to act as a single Zjednoczenie Przemysłu Farmaceutycznego "Polfa" ("Polfa" Union of the Pharmaceutical Industry), operating under standardized names created by adding the "Polfa" bit to their respective previous names, which was to symbolize the Polish pharmaceutical industry. Zjednoczenie Przemysłu Farmaceutycznego "Polfa" was managed centrally (Kurkowska-Bondarecka, 1995). Figure 1 presents the geographical locations of the companies operating in the "Polfa" group in 1980.

After 1989, most companies operating under the 'umbrella' of Zjednoczenie Przemysłu Farmaceutycznego "Polfa" became privatized and, in consequence, none of the unions in question exists today. But it's worth noting that there are still companies that have maintained the logo, or the name of a given union for e.g. marketing reasons. 
Figure 1. "Polfa" plants in 1980

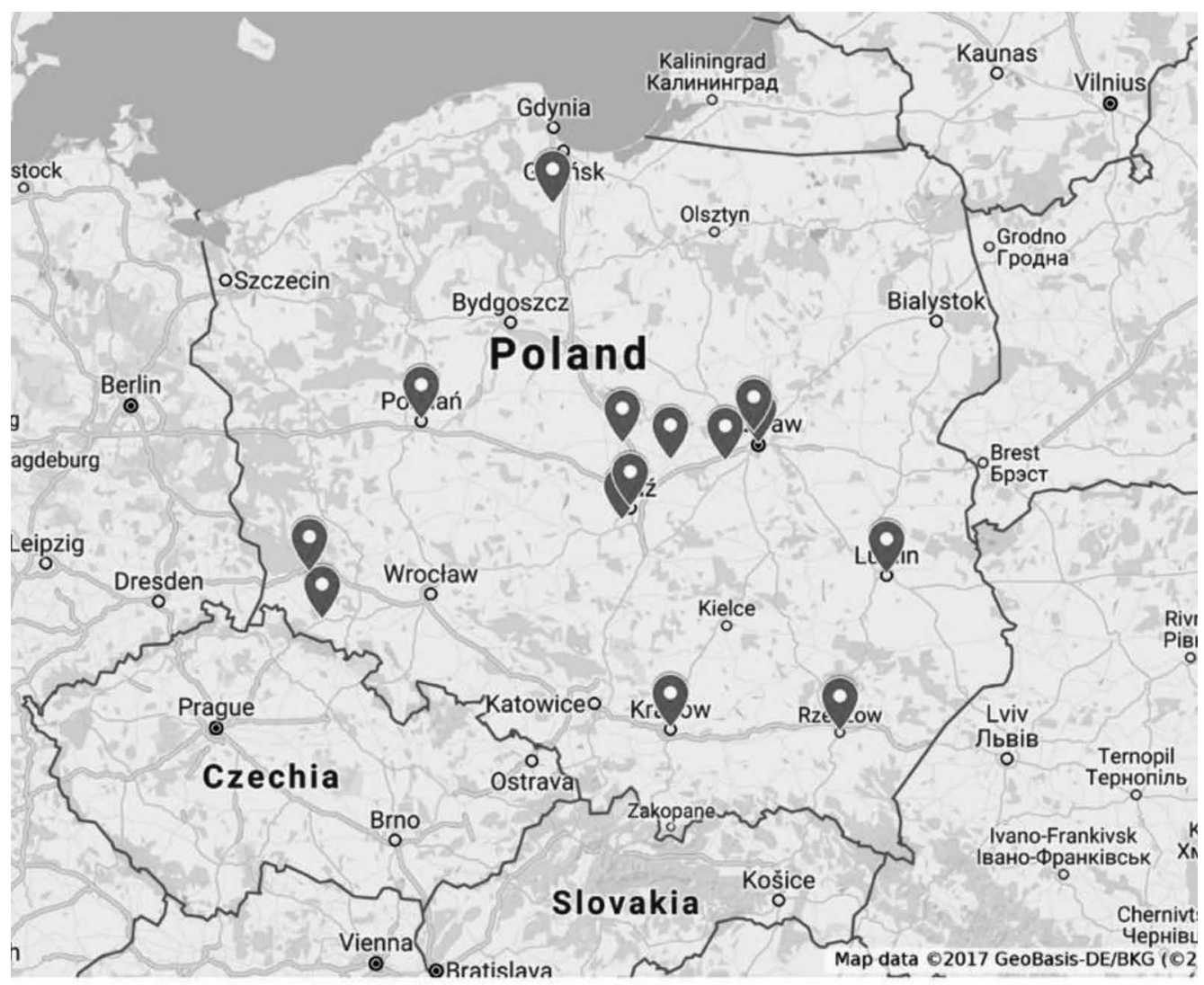

"POLFA" FACTORIES IN 1980s'
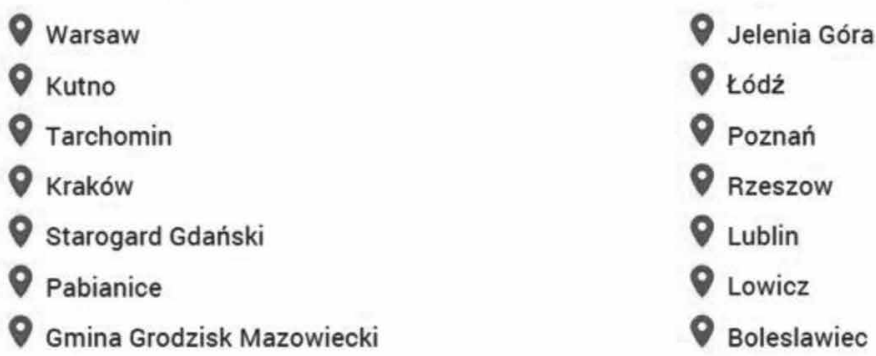

Source: own work based on Kurkowska-Bondarecka (1995, p. 89).

I have analysed four Polish corporate histories (provided in the form of books) of three POLFA pharmaceutical plants that were members of the abovementioned Zjednoczenie Przemysłu Farmaceutycznego "Polfa" (see: Table 1 presenting the characteristics of chosen corporate histories): 
- Krakowskie Zakłady Farmaceutyczne "Polfa” "'Polfa” Kraków Pharmaceutical Works),

- Warszawskie Zakłady Farmaceutyczne "Polfa” "Polfa” Warsaw Pharmaceutical Works),

- Tarchomińskie Zakłady Farmaceutyczne "Polfa” ("Polfa” Tarchomin Pharmaceutical Works).

It's quite important to stress that only one of these corporate histories was published because of a centenary of the company.

I focused on the qualitative comparative content analysis of corporate histories in search of common themes, dominant narratives, dominant logic and reinterpretations of the business reality between and during wars, in the period of socialism and subsequent transition to market economy. The material was coded using MAXQDA software. The analysis covered over 450 pages in total.

Table 1. Characteristics of chosen corporate histories

\begin{tabular}{|c|c|c|c|c|c|}
\hline Company & $\begin{array}{c}\text { Year of } \\
\text { establish- } \\
\text { ment }\end{array}$ & Age & $\begin{array}{c}\text { Year of } \\
\text { publication of } \\
\text { corporate history }\end{array}$ & $\begin{array}{l}\text { Author of the } \\
\text { corporate } \\
\text { history }\end{array}$ & Present name \\
\hline $\begin{array}{l}\text { Krakowskie } \\
\text { Zakłady } \\
\text { Farmaceutyczne } \\
\text { "Polfa" }\end{array}$ & 1930 & 87 & $\begin{array}{l}\text { - } 1967 \\
\text { (Polish People's } \\
\text { Republic) } \\
\text { - } 2016 \\
\text { (Third Polish } \\
\text { Republic) }\end{array}$ & $\begin{array}{l}\text { - Polfa } \\
\text { employee } \\
\text { - Researcher } \\
\text { specializing } \\
\text { in economic } \\
\text { history }\end{array}$ & $\begin{array}{l}\text { Teva Pharmaceuticals } \\
\text { Polska sp. z 0.0. / Teva } \\
\text { Operations Poland } \\
\text { (TEVA is one of the } \\
\text { leading pharmaceutical } \\
\text { companies in the world) }\end{array}$ \\
\hline $\begin{array}{l}\text { Warszawskie } \\
\text { Zakłady } \\
\text { Farmaceutyczne } \\
\text { "Polfa" }\end{array}$ & 1824 & 193 & $\begin{array}{l}1975 \\
\text { (Polish People's } \\
\text { Republic) }\end{array}$ & Polfa employee & $\begin{array}{l}\text { Polfa Warszawa S.A } \\
\text { (Polfa has been part } \\
\text { of the Polpharma Group) }\end{array}$ \\
\hline $\begin{array}{l}\text { Tarchomińskie } \\
\text { Zakłady } \\
\text { Farmaceutyczne } \\
\text { "Polfa" }\end{array}$ & 1823 & 194 & $\begin{array}{l}\text { - } 2013 \\
\text { (Third Polish } \\
\text { Republic) }\end{array}$ & unknown & $\begin{array}{l}\text { Polfa Tarchomin S.A. } \\
\text { ( } 85.69 \% \text { of shares } \\
\text { is owned by the Treasury) }\end{array}$ \\
\hline
\end{tabular}

Source: own work. 


\section{Empirical findings}

A preliminary analysis of corporate histories of the three "Polfa" works has revealed many more differences in narratives between corporate histories published in the period of the Polish People's Republic (1952-1989) and in the Third Polish Republic (1989 - present) than similarities. During my analysis, I followed Delahaye et al. (2009) standards of the "genre of corporate history". I will discuss the outcomes of my analysis starting from the similarities found between the aforementioned corporate histories.

\section{Similarities - Formal features}

All of the examined corporate histories were made available in the form of a book with indicated names of their authors. There is one exception, though - there is no clear identification of the author of the corporate history connected with the centenary of "Polfa" plant. The paratext describes material outside the narrative. Each title features the proper name of the company. In the case of three of them, the title had the word history inside, or showed the time horizon. There is no clear listing of the content in corporate histories written by "Polfa" employees. Stories begin from the first pages. In the case of the history published by an academic, there are table of contents, footnotes, a bibliography, and an index together with a clear indication of the sources used to develop the publication. Additionally, in the analysed corporate histories, there are photo records and archives of copies of documents featured at random in the narrative, functioning as pieces of evidence to testify to the wealth of a given organization's life and assets. Meanwhile, the various artefacts and products serve as a commemoration of the company's activities or achievements.

\section{Similarities - Thematic content}

The narration is usually linear, impersonal. We can see that the narrator uses personal pronouns such as "we" or "our" in the corporate history published in 1975. A thematic chapter division is found in all of the analysed corporate histories. In each history, there is much content devoted to the founder of a given company, featured always together with a photo. Another typical - and always present - feature was a description of the family of the founder and their role in the establishment of their company. In the case of corporate histories written by "Polfa" employees, we can notice an absence of competitors and, as stated by Delahaye et al. (2009, p. 36), "the plot unfolds in a social and economic environment where concerns with competitors are secondary to, say, consumer taste, national stability or overall economic growth". All of the featured corporate histories borrow themes from 
national history and take advantage of them to describe the development of each respective company. The analysis confirms that a corporate history offers a rhetorical parallel between a given company and other national institutions whose past is known among the target reader audience. This way, each such company becomes itself a kind of a national institution (Williams, 1994; Powell, 1991). All the corporate histories being the subject of the analysis associated company events with the national themes and with the social and economic environment of the time.

\section{Differences - Formal features}

One of the first differences was the format of the books in question. In the case of old corporate histories $(1967 ; 1975)$, the books were rather small, one of them was even a pocket version while the modern $(2013 ; 2016)$ ones follow the standard A5 size. The proportion of images to textual content leans towards a predominance of imagery in the case of old corporate histories. Photos are arranged around the textual content. In the corporate history from 1967, there are a lot of images of medicines and the company's infrastructure. In the case of the story from 1975, photos feature employees in majority. In the case of the history from 2013, images present all aspects of the company - from company buildings to employees. But even when there is an employee in the photo, the description does not concern the featured person. Moving on to 2016, the photos are only appendixes, and we have only 14 images, showing mainly "Polfa" buildings.

Additional differences that the author has discovered is different terminology used in particular corporate histories - see Table 2.

Table 2. Language differences in corporate histories - examples

\begin{tabular}{|c|c|c|}
\hline Term & $\begin{array}{c}\text { Old corporate history } \\
\text { - Polish People's Republic }\end{array}$ & $\begin{array}{l}\text { New corporate history } \\
\text { - Third Polish Republic }\end{array}$ \\
\hline employee & $\begin{array}{l}\text { "robotnik"( } \approx \text { "worker"), } \\
\text { "towarzysz" ( } \approx \text { "comrade") }\end{array}$ & “person” \\
\hline entrepreneur & "przemysłowiec" (₹"industrialist") & "entrepreneur", "businessman" \\
\hline $\begin{array}{l}\text { "upaństwowienie" } \\
\text { ( } \approx \text { "nationalization") }\end{array}$ & $\begin{array}{l}\text { "przymusowy zarząd państwowy" } \\
\text { ( } \approx \text { compulsory state management") }\end{array}$ & $\begin{array}{l}\text { "upaństwowienie" } \\
\text { ( } \approx \text { "nationalization") }\end{array}$ \\
\hline sales department & $\begin{array}{l}\text { "wydział propagandy lekarskiej" } \\
\text { ( } \approx \text { "medical propaganda division") }\end{array}$ & sales department \\
\hline advert/leaflet & $\begin{array}{l}\text { occasional print, printed and visual } \\
\text { material }\end{array}$ & advert/leaflet \\
\hline
\end{tabular}

Source: own work. 
It is also worth adding that the oldest analysed corporate history (1967) was written in three languages - Polish, English, and Russian. The text was divided into three columns - each for one language.

\section{Differences - Thematic content}

What is very interesting is that there are differences in the narratives between corporate histories published even in the same historical time-frame - in 1967 and 1975. In the case of the corporate history from 1967, there is a lot of information about company development. The described company is presented as a very successful business, playing the key role in the Polish pharmaceutical industry. The text stresses the investments made in the development of the company's infrastructure, machines, and technology Moreover, all new recipes for medicines and new production processes developed within the company are discussed at large. The text concentrates on the company's significant achievements.

On the other hand, in the case of the history from 1975, employees are the central theme. There are a lot of employees' photos with detailed descriptions of the people shown in the photos. The featured persons are always described with the title, name, surname, date of birth, and home address. We can also find agreements signed by employees. There are even photos of special occasion cards from 1948. We can find direct quotes from company staff members, which is absent from the other history. Directors of unions are named and described with due care and detail. The text draws attention to employees working for a long time in the company and to their contribution to the company. The narrative presents the problems employees experienced during their work (lack of tools, spare parts, etc.) and how they effectively coped with them. The description highlights employees' commitment and involvement in the company's success. There is also information about the inventions created by company employees and about the awards employees were granted, together with a complete list of employees who received them (9 pages). In addition to that, all the descriptions are very rich and detailed. We can find exhaustive descriptions of organizational structures and official procedures and, for example, the dimensions of chemical facilities such as plant buildings. There is even a table covering the consumption of electric power and expenditure on occupational health and safety matters. These descriptions appear very natural, with a good example being the description of the activity of Zakład Organopreparatów (Organic Preparation Works) - "przerób narządów zwierząt i moczu klaczy i surowicy” ("processing animal organs, mare urine, and serum”) (Kikta, 1975, p. 40). Furthermore, the featured description is often emotionally marked, e.g. "technologie produkcji opracował 
bardzo zdolny inżynier" ("production technologies were developed by a very talented engineer") (Kikta, 1975, p. 45) and vivid - "pachniało jeszcze dymem zgliszcz" ("the smell of smouldering ruins lingered still in the air") (Kikta, 1975, p. 52).

The central themes of the "Polfa" corporate histories from 2013 and 2016 are the production processes and the medicines produced. But it's worth mentioning that in the case of the corporate history published in 2013 on the company's centenary year of operation, the narrative seems to portray virtually everything from a present perspective. Another highlight is that "Polfa" CSR activities are discussed to a broader extent in the case of years 1967 and in 2013. In the case of the 1975 corporate history, there is no informational about the impact of the company on the local environmental and social matters. In 2016, in turn, the emphasis is placed on ecological issues.

\section{Discussion and conclusions}

The paper offers an examination of four corporate histories according to standards covered by Delahaye et al. (2009, p. 36). First of all, it contributes to research on "uses of the past" in organization studies. As stated by Smith and Simone (2017, p. 335), there is "little research on the history of the corporate use of history". Apart from the "rapidly improving understanding of how present-day firms use history to communicate with stakeholders, we know less about how the practice originated". As mentioned before, in Poland, companies began to publish their corporate histories mostly in the period of socialism. This is due to the fact that during this time, the anniversaries were an opportunity to present the achievements of the government and different work establishments. Therefore, this study brings new interesting insights into the understanding of the role of corporate history over the course of time.

Second, this research project involves a unique research setting. As stated by Amatori and Jones (2003), Central and Eastern Europe is one of the relatively most underdeveloped regions when it comes to historical studies. Contributing the example of Poland offers a unique perspective on the studies of narrative.

Third, the study reveals that corporate history depends on the state authority in power at a given time and its dominant narrative (varieties of socialism). They were created rather in a constructivist vein than in a realist one (Foster et al., 2016). Previous studies focused on managers and the ways how they might take advantage of different external circumstances by offering certain scenarios and narratives 
according to their intentions, thus triggering the desired effects. We can find that companies shape and tamper with their past to be viewed as more legitimate by their stakeholders or to gain competitive advantage (McGaughey, 2013). The "Polfa" case proves that history is used selectively by organizational actors (Brunninge, 2009), but in addition to that, this paper shows that corporate history is not only shaped by firms' managers, but also that state authorities are able - and often inclined - to take advantage of it, re-telling the past for their own benefit and legitimacy. The study shows the impact of the government in building corporate identity.

For example, the year 1967 is the period when Gomułka was in power (period of 1956-1970). The public domain was dominated by collectivism and a constant emphasis on the need for collective efforts taken to the advantage of all. When giving a speech, Gomułka always tried to highlight all aspects of the economic growth of the country in a very meticulous way. This is visible in the corporate history from the said year, focusing mainly on the company's achievements, successes, and great development. In the case of the 1975 corporate history, in turn, we can see that people and their participation in the company's success are the most important assets for the company. Employees are successful and they can make great careers. This relates to the propaganda of success affirmed by Gierek, who was in power in 1970-1980. The propaganda involved creating and promoting 'role models' - hardworking and successful people who were to become examples for others to follow. One of Gierek's slogan was "let Poland grow strong and people be prosperous". He promised industrial modernization which was supposed to improve people's living conditions. This was a period when one of the priorities was to 'resurrect' the idea of 'udarnik' popular in Stalin's Soviet Union. Udarnik was a super-productive, enthusiastic labourer, a model representative of a movement which assumed combining professional and private success. This was also when the media gained more power and recognition, with printing houses becoming modernized and developed.

Fourth, the presented research shows also that narratives do have an impact on society. The corporate histories presented in this research offer sharp and accurate illustration of the phenomena and events taking place in the cultural and organizational sphere of the time. The analysis thereof not only provides people with knowledge of the history of particular company and of their routines and practices, but becomes also a valuable source of historical context (e.g. for educators). Additionally, narratives make the past meaningful, so they influence the social construction of our reality (Lubinski, 2018). 
Finally, this study has implications also for business practice. The "Polfa" case shows that a corporate history is, on the one hand, a product of a company, but on the other, it is a company's strategic resource (Suddaby et al., 2010). It can be treated as company heritage. Corporate histories can help current managers understand the roots of their companies and learn how the past influences their present performance. Furthermore, this study shows that organizational actors can develop narratives fitting their political purpose best. The historical context can be treated as a source for their legitimization (as described by Brunninge, 2009).

\section{Limitations and further studies}

There is still a need for further research concerning narratives. This research can contribute to a number of in-depth debates in the discipline of business history, including topics such as the use of history, corporate memory, uncertainty, and improvisation (Scranton and Fridenson, 2013). Of course, the study covered in this paper is not without limitations. First, the author used content analysis to study corporate histories. This qualitative, interpretative research technique can be considered subjective. Even though the author has used data triangulation methods to improve the reliability and validity of the research, other scholars might have stressed different issues arising from the studied data. Second, the corporate histories concerned three different "Polfa" plants. A study of a corporate history of a single plant - published in a different period of time - could bring more insight into the context of historical narratives. Finally, the data used in the study (i.e. corporate histories) comes from one of the most important industries in the period of socialism. But there were more industrial groups to consider. It might therefore be interesting to study and compare the corporate histories of additional companies from different industries such as mining or steel manufacturing.

\section{References}

Alvesson, M. and Kärreman, D. (2000). Taking the linguistic turn in organizational research: Challenges, responses, consequences. The Journal of Applied Behavioral Science, 36(2): 136-158, https://doi.org/10.1177/0021886300362002

Amatori, F. and Jones, G. (eds.) (2003). Business History around the World. Cambridge University Press, https://doi.org/10.1017/CBO9780511512100

Barry, D. and Elmes, M. (1997). Strategy retold: Toward a narrative view of strategic discourse. Academy of Management Review, 22(2): 429-452, https://doi.org/10.5465/amr.1997.9707154065

Boje, D.M. (1991). Organizations as storytelling networks: A study of story performance in an office-supply firm. Administrative Science Quarterly, 36: 106-126, https://doi.org/10.2307/2393432 
Boje, D.M. (1995). Stories of the storytelling organization: A postmodern analysis of Disney as Tamara-land. Academy of Management Journal, 38(4): 997-1035.

Boje, D.M., Oswick, C. and Ford, J.D. (2004). Language and organization: The doing of discourse. Academy of Management Review, 29(4): 571-577, https://doi.org/10.5465/amr.2004.14497609

Brunninge, O. (2009). Using history in organizations: How managers make purposeful reference to history in strategy processes. Journal of Organizational Change Management, 22(1): 8-26, https://doi.org/10.1108/09534810910933889

Bucheli, M. and Wadhwani, D. (eds.) (2014). Organzations in Time: History, Theory, Methods. Oxford: Oxford University Press.

Carroll, C.E. (ed.) (2016). The SAGE Encyclopedia of Corporate Reputation. SAGE Publications, https://doi.org/10.4135/9781483376493

Clark, P. and Rowlinson, M. (2004) The Treatment of History in Organisation Studies: Towards an 'Historic Turn'? Business History, 46(3): 331-352, https://doi.org/10.1080/0007679042000219175

Czarniawska-Joerges, B. (1997). Narrating the organization: Dramas of institutional identity. Chicago, IL: University of Chicago Press.

Delahaye, A., Booth, C., Clark, P., Procter, S. and Rowlinson, M. (2009). The genre of corporate history. Journal of Organizational Change Management, 22(1): 27-48, https://doi.org/10.1108/09534810910933898

Durepos, G., Mills, A.J. and Mills, J.H. (2008). Tales in the manufacture of knowledge: Writing a company history of Pan American World Airways. Management $\mathcal{F}$ Organizational History, 3(1): 63-80, https://doi.org/10.1177/1744935908090998

Foster, W.M., Coraiola, D.M., Suddaby, R., Kroezen, J. and Chandler, D. (2017). The strategic use of historical narratives: a theoretical framework. Business History, 59(8): 1176-1200, https://doi.org/10.1080/00076791.2016.1224234

Foster, W.M., Coraiola, D. and Suddaby, R.R. (2016). Useful rhetorical history: An ideographic analysis of Fortune 500 corporations. Academy of Management Proceedings, 1 , https://doi.org/10.5465/ambpp.2016.120

Jones, G. and Sluyterman, K. (2003). British and Dutch business history. W: F. Amatori and G. Jones, Business history around the world. Cambridge, https://doi.org/10.1017/CBO9780511512100.007

Gabriel, Y. (2004). The narrative veil: Truthand untruths in storytelling. In Y. Gabriel (ed.), Myths, Stories and Organizations: Premodern narratives for our times. Oxford: Oxford University Press.

Gatti, M.C. (2011). The language of competence in corporate histories for company websites. Journal of Business Communication, 48(4): 482-502, https://doi.org/10.1177/0021943611414543

Jastrząb, M. (2011). Historia biznesu: czego uczy i czy pomaga zrozumieć światowy kryzys?, Master of Business Administration, 6: 36-47.

Kikta, T. (1975). Karty z historii Warszawskich Zakładów POLFA. Warszawa: PZWL.

Kołodko, G.W. (2005). The Polish Miracle. Lessons for the Emerging Markets. Aldershot: Ashgate Publishing Ltd.

Kostera, M., Sławecki, B. (2014). Opowieści o tworzeniu organizacji. Historiografia przedsiębiorczości jako program badawczy i praktyczny. Problemy Zarzqdzania, 12(3): 47-63.

Koźmiński, A.K. (1993). Catching Up? Case Studies of Organizational and Management Change in the Ex-Socialist Block. Albany: Suny Press.

Koźmiński, A.K. (2008). Management in Transition. Warszawa: Difin.

Kurkowska-Bondarecka, K. (1995). Historia polskiego przemysłu farmaceutycznego. Stowarzyszenie Inżynierów i Techników Przemysłu Chemicznego. Zarząd Główny.

Lubinski, C. (2018). From 'History as Told'to 'History as Experienced': Contextualizing the Uses of the Past. Organization Studies, 39(12): 1785-1809, https://doi.org/10.1177/0170840618800116 
Maclean, M., Harvey, C. and Stringfellow, L. (2017). Narrative, metaphor and the subjective understanding of historic identity transition. Business History, 59(8): 1218-1241, https://doi.org/10.1080/00076791.2016.1223048

Matera, R., Pieczewski, A. (eds.) (2011). Przeglq̨d badań nad historiq gospodarczq w XXI wieku. Łódź: Wydawnictwo Uniwersytetu Łódzkiego.

McGaughey, S.L. (2013). Institutional entrepreneurship in North American lightning protection standards: Rhetorical history and unintended consequences of failure. Business History, 55(1): 73-97, https://doi.org/10.1080/00076791.2012.687537

Meardi, G., Gardawski, J. and Molina, O. (2015) The dynamics of tripartism in post-democratic transitions: comparative lessons from Spain and Poland. Business History. 57(3): 398-417, https://doi.org/10.1080/00076791.2015.1044516

Mikołajewska-Zając, K. (2014), Alienation and rush towards change: introducing capitalism to a state-owned Polish enterprise. Oral History, 2: 69-80.

Morawski, W. (2017). Identity and Diversity: What Shaped Polish Narratives Under Communism and Capitalism. Journal of Management and Business Administration. Central Europe, 25(4): 209-243, https://doi.org/10.7206/jmba.ce.2450-7814.215

Morawski, W. (2011). Dzieje gospodarcze Polski. Warszawa: Difin.

Mordhorst, M. and Schwarzkopf, S. (2017). Theorizing narrative in business history. Business History, 59(8): 1155-1175, https://doi.org/10.1080/00076791.2017.1357697

Pikos, A. and Olejniczak, T. (2017). Business History in Poland: Current State and Future Potential. Journal of Management and Business Administration. Central Europe, 25(3): 55-77, https://doi.org/10.7206/jmba.ce.2450-7814.199

Popp, A. and Fellman, S. (2017). Writing business history: Creating narratives. Business History, 59(8): 1242-1260, https://doi.org/10.1080/00076791.2016.1250742

Powell, D. (1991). Counter Revolution: The Tesco Story. London: Grafton Books.

Putnam, L.L. and Fairhurst, G.T. (2001). Discourse analysis in organizations. In: F.M. Jablin and L.L. Putnam (eds.), The new handbook of organizational communication: Advances in theory, research and methods. Sage.

Scranton, P. and Fridenson, P. (2013). Reimagining Business History. Baltimore: Bal The Johns Hopkins University Press.

Smith, A., and Simeone, D. (2017). Learning to use the past: the development of a rhetorical history strategy by the London headquarters of the Hudson's Bay Company. Management $\&$ Organizational History, 12(4): 334- 356, https://doi.org/10.1080/17449359.2017.1394199

Stanciu, L. (2006) Free-Standing Companies in the Oil Sector in Romania and Poland Before 1948: Typologies and Competencies. Business History, 42(4): 27-66, https://doi.org/10.1080/00076790000000301

Suddaby R., Foster W.M., Trank C.Q. (2010). Rhetorical history as a source of competitive advantage. Advances in Strategic Management, 27: 147-173, https://doi.org/10.1108/S0742-3322(2010)0000027009

Teece, D. and Pisano, G. (1994). The dynamic capabilities of firms: an introduction. Industrial and corporate change, 3(3): 537-556, https://doi.org/10.1093/icc/3.3.537-a

Williams, B. (1994). The Best Butter in the World: A History of Sainsbury's. London: Ebury Press.

Yates, J. and Orlikowski, W.J. (1992). Genres of organizational communication: A structurational approach to studying communication and media. Academy of Management Review, 17(2): 299-326, https://doi.org/10.5465/amr.1992.4279545

Ybema, S. (2014). The invention of transitions: History as a symbolic site for discursive struggles over organizational change. Organization, 21(4): 495-513, https://doi.org/10.1177/1350508414527255 